DOI: 10.14451/2.127.61

\title{
АКТУАЛИЗАЦИЯ ПРОБЛЕМ КАДРОВОГО МЕНЕДЖМЕНТА ПО РЕЗУЛЬТАТАМ ИНТЕРВЬЮИРОВАНИЯ РАБОТНИКОВ НЕГОСУДАРСТВЕННОГО УЧРЕЖДЕНИЯ ЗДРАВООХРАНЕНИЯ
}

\author{
(c) 2019 Блинов Сергей Валерьевич \\ кандидат медицинских наук \\ доцент кафедры «Организация здравоохранения и общественное здоровье» \\ Медицинский университет «Реавиз» \\ 443001, г. Самара, ул. Чкалова, 100 \\ E-mail: sekretar@dkb63.ru \\ (c) 2019 Кузьмина Наталья Михайловна \\ доктор экономических наук, профессор \\ заместитель главного врача по кадрам и правовым вопросам \\ Дорожная клиническая больница на станции Самара \\ открытого акционерного общества «Российские железные дороги» \\ 443041, г. Самара, ул. Агибалова, 12 \\ E-mail:hrm-kuzmina@yandex.ru \\ (c) 2019 Ревина Светлана Николаевна \\ профессор, доктор юридических наук, заведующая кафедрой публичного права \\ Самарский государственный экономический университет \\ 443090, г. Самара, ул. Советской Армии, 141 \\ E-mail: 29.revina@mail.ru \\ () 2019 Сидорова Анна Викторовна \\ старший преподаватель кафедры публичного права \\ Самарский государственный экономический университет \\ 443090, г. Самара, ул. Советской Армии, 141 \\ E-mail:an.sido@bk.ru
}

Статус службы по управлению персоналом (СУП) определяется повышенным вниманием руководителей к кадровым вопросам. СУП на уровне высшего руководства воспринимается не только как исполнитель, но как инициатор и транслятор изменений в организации. В статье представлены результаты авторского исследования, проведенного в рамках одного структурного подразделения учреждения здравоохранения (УЗ) и позволившего своевременно принять актуальные управленческие решения.

Ключевые слова: учреждение здравоохранения, интервью, управление персоналом, руководитель, исполнитель.

Исследование проводилось в форме интервью. Интервьюирование подразумевает разработку сценария интервью в виде примерного перечня вопросов и его последующую корректировку в ходе диалога с собеседником в целях получения необходимой достоверной информации [1, с.14-19]. Использование не только основных вопросов, но и «прощупывающих», «уточняющих», «наводящих», «провокационных» вопросов позволяет добиться достоверных ответов.

Первая группа вопросов позволяли снять напряжение у каждого из интервьюируемых, разговорить, расположить к себе, именно они позволили реализовать тематический каталог интервью, обеспечив готовность опрашиваемых искренне отвечать на предлагаемые вопросы и поддерживать беседу. Свобода в выборе и чередовании, самой постановке вопросов позволили эксперту, проводящему беседу, настроиться на ситуацию и персону конкретного сотрудника, получить информацию достоверную, иногда неожиданную, которую невозможно получить никаким другим способом. Внимательное изучение деталей и критический анализ информации по формальным и содержательным признакам, 
наблюдение за собеседником, вербальная и невербальная коммуникации, полнота изложения, отсутствие или наличие пробелов в изложении позволили оценить и степень искренности, и попытки манипуляции, и наличие определенных опасений у сотрудников СУП.

Продолжительность проведения интервью определялась с учетом личностных особенностей, временных границ («давление временем»), потенциальной возможности «разговорить» опрашиваемого и обеспечить правдивые ответы.

Перечень основных вопросов включал 48, примерный список «уточняющих» и «наводящих» - 50. Время интервьюирования (расчетное) было определено в 45 минут, а фактическое приведено в таблице 1.

Практически все работники (за исключением 1 чел.) получали высшее образование заочно и при этом они утверждают, им его недостаточно, а приобретенные знания не пригодились.
Все уверены, что высшее образование для исполнения должностных обязанностей не нужно, даже начальник отдела. Но специальных знаний не хватает всем:

- юридических и кадрового учета (документооборота);

- информации Минздрава о требованиях к специалистам;

- знания программных продуктов;

- информации по юридическим и кадровым нововведениям;

- информации о повышении квалификации вообще и, в частности, по нововведениям (приказ № 302);

- юридических, может быть, трудового права;

- юридических и конкретной практики.

Удивляет в такой ситуации выбор ВУЗа и специальности (табл. 2).

Особый акцент был сделан на юридических

Таблица 1. Время интервьюирования сотрудников СУП

\begin{tabular}{|c|l|c|}
\hline № & \multicolumn{1}{|c|}{ ФИО, должность } & Фактическое время \\
\hline 1 & А, специалист по управлению персоналом 1 категории & 1 час 49 мин \\
\hline 2 & Б, начальник отдела по управлению персоналом & 3 час 20 мин \\
\hline 3 & В, специалист по управлению персоналом 1 категории & \\
\hline 4 & Г, специалист по управлению персоналом 1 категории & 2 час 30 мин \\
\hline 5 & Д, специалист по управлению персоналом 1 категории & 2 час 16 мин \\
\hline 6 & Е, ведущий специалист по управлению персоналом & 1 час 26 мин \\
\hline 7 & Ж, специалист по управлению персоналом 1 категории & \\
\hline 8 & 3, специалист по управлению персоналом 1 категории & 1 час 49 мин \\
\hline
\end{tabular}

Таблица 2. Оконченное учебное заведение и полученная специальность

\begin{tabular}{|c|c|c|c|}
\hline № & ФИО, должность & Учебное заведение & Специальность \\
\hline 1 & $\begin{array}{l}\text { A, специалист по управлению } \\
\text { персоналом отдела } 1 \text { категории }\end{array}$ & СПТУ № 25 & Оператор ЭВМ \\
\hline 2 & $\begin{array}{l}\text { Б, начальник отдела } \\
\text { по управлению персоналом }\end{array}$ & $\begin{array}{l}\text { Издательско-полиграфический техникум, } \\
1998 \\
\text { Российский университет кооперации, } 2011\end{array}$ & $\begin{array}{l}\text { Бухгалтер } \\
\text { экономист-менеджер }\end{array}$ \\
\hline 3 & $\begin{array}{l}\text { В, специалист по управлению } \\
\text { персоналом отдела } 1 \text { категории }\end{array}$ & Куйбышевский авиационный институт, 1980 & инженер-математик \\
\hline 4 & $\begin{array}{l}\text { Г, специалист по управлению } \\
\text { персоналом }\end{array}$ & $\begin{array}{l}\text { Самарский институт инженеров ж.д. } \\
\text { транспорта, } 2005\end{array}$ & $\begin{array}{l}\text { «Инженерные систе- } \\
\text { мы и технологии», } \\
\text { инженер }\end{array}$ \\
\hline 5 & $\begin{array}{l}\text { Д, специалист по управлению } \\
\text { персоналом отдела } 1 \text { категории }\end{array}$ & $\begin{array}{l}\text { Самарский государственный педагогический } \\
\text { университет, } 2004\end{array}$ & «Психология» \\
\hline 6 & $\begin{array}{l}\text { Е, ведущий специалист } \\
\text { по управлению персоналом }\end{array}$ & $\begin{array}{l}\text { Самарский институт инженеров ж.д. } \\
\text { транспорта }\end{array}$ & $\begin{array}{l}\text { «Инженерные систе- } \\
\text { мы и технологии», } \\
\text { инженер }\end{array}$ \\
\hline 7 & $\begin{array}{l}\text { Ж, специалист по управлению } \\
\text { персоналом отдела } 1 \text { категории }\end{array}$ & $\begin{array}{l}\text { Самарский государственный технический } \\
\text { университет, } 2011\end{array}$ & $\begin{array}{l}\text { «Управление персо- } \\
\text { налом», менеджер }\end{array}$ \\
\hline 8 & $\begin{array}{l}\text { 3, специалист по управлению } \\
\text { персоналом отдела } 1 \text { категории }\end{array}$ & Поволжский институт бизнеса, 2006 & менеджер \\
\hline
\end{tabular}


вопросах и обозначении необходимости юриста в штате отдела.

Специальные программы (курсы, семинары и т.п) сотрудники не посещали, за исключением 1 чел. (1 раз), при этом сертификаты, имеющиеся в личных делах, подтверждают иное. Необходимо понимать, что в повседневной действительности, однодневные курсы и лекции можно считать отвлечением от основной работы, знаний они не прибавляют и в памяти не остаются.

Открыто обсуждать проблемы профессиональной деятельности с коллегами или посторонним человеком - экспертом они готовы, с начальником отдела, руководством УЗ и представителем профсоюза - нет.

Из рабочих проблем (ответили только 33,3\%) 1 работника ежедневно беспокоит правильность оформления приказов и заявлений, а другого работа в режиме «открытая дверь». Еженедельно беспокоят 1 работника жалобы, проблемы обучения в системе НMO, в том числе он-лайн, еще 1 сотрудник обозначил внешние проверки, требующие специальной подготовки копий документов и информации для руководства.

Один сотрудник обратил внимание на специфику работы - «не нужно копить приказы, лучше обрабатывать их в текущем порядке»; 1 раз в квартал (ответили искренне 50\%) - оформление санаторно-курортного лечения, отчеты ВЭК; текущие отчеты; запросы, мобрезерв, воинский учет и списки военнообязанных. Раз в год или реже беспокоят работников СУП ежегодный отчет (1 чел.), отчеты вообще (1 чел.), списки на премирование для экономистов (1 чел.) и процедура лицензирования (1 чел.).

Взаимоотношения в отделе по управлению персоналом (в первую очередь межличностные и во вторую - профессиональные) в целом устраивают всех, кроме начальника, поскольку она уверена, что ее считают «мягким» руководителем. Но сотрудники хотят большего взаимодействия с начальником.

Взаимоотношения в УЗ устраивают только $33,3 \%$ сотрудников СУП, другие считают, что жалобы со стороны расчетной группы; дрязги, докладные, отсутствие реальной поддержки и эффективных взаимосвязей усложняют ситуацию и не позволяют получить ответы на значимые вопросы.

При этом предложения по улучшению деятельности СУП высказали только 2 сотрудника:

- сменить начальника или учить ее рабо- тать;

- повысить профессионализм, обеспечить переобучение, выделить время на подготовку приказов.

Улучшить взаимодействие СУП с другими службами УЗ можно, по мнению сотрудников только в том случае, если коммуникации будут зафиксированы в Положениях об СП. Проведение совместных обсуждений и совещаний; обеспечение горизонтального взаимодействия и коллегиального решения вопросов; своевременное освоение программ.

Считают необходимым свое участие в улучшении деятельности отдела только 4 сотрудника, причем только устно и внутри отдела, в условиях взаимозаменяемости, 1 чел. - «Могу...», еще 1 уверен, что «начальник справится, если захочет, и отдел без меня тоже справится - взаимозаменяемость».

Половина сотрудников СУП полагает, что должно быть время, свободное от посещений сотрудников, для работы с документами, но объем требуемого времени определяют очень по-разному - от 1,5 час. до целого рабочего дня.

Тема совещаний и коллегиального решения вопросов в СУП, с сотрудниками других служб и общения с руководством УЗ была существенно расширена и дополнена в рамках индивидуального интервьюирования, при этом каждый обращал внимание на то, что инициировать подобные мероприятия должна другая сторона или начальник отдела [3, с.83-90]. Сотрудники СУП полагают, что совещания в отделе и с другими службами необходимы, это нужно зафиксировать в Положениях (или регламентах и положениях). По их мнению, совместные обсуждения улучшат взаимодействие СУП с другими службами УЗ и обеспечат взаимосвязь руководителей.

Это очень тревожный момент, сотрудники любят поговорить, у них есть для этого время в рамках рабочего дня, коллегиальное принятие решений обеспечивает «круговую поруку» и свидетельствует о недостатке компетентности и персональной ответственности.

Кроме того, сотрудники настаивают на «развитии горизонтальных коммуникаций и исключении из процесса начальника СУП», что свидетельствует о недоверии к нему как руководителю и профессионалу. Кроме того, это никак не согласуется с их желанием контроля и оценки личного вклада и противоречит не только логике организационной структуры, так и сложив- 
шимся взаимоотношениям.

Идеальный начальник отдела по управлению персоналом в глазах сотрудников выглядит как компетентный, дистантный, контролирующий, организовывающий, конкретный. 50\% сотрудников высказываются еще более определенно: 1 чел. указывает «меньше болтать обо всем», еще 1 - «Как (указывает персону)», еще 1 - вспоминает другого начальника («Была строгой, тоже много чего не знала из повседневной деятельности, в том числе программ, но могла всех организовать, заставить работать и ее уважали» и другая (указывает персону) согласовывала документы, например, Положение о СУП Уз.

Руководство УЗ может улучшить работу отдела, сократив количество поручений, согласовывая заранее изменение штата, пересмотрев Положения и должностные инструкции, обеспечив надлежащий вид архивации кадровых документов.

Качество обратной связи с высшим руководством устраивает только 1 работника, но все так или иначе склоняются к мнению, что проявить инициативу должно именно высшее руководство, «ВЕСЬ ОТДЕЛ пошел бы на беседу, чтобы узнать мнение руководителя».

На вопрос «Каким образом можно улучшить качество обратной связи с начальником отдела?» сотрудники отвечают:

- не представляю;

- изменить состав трудового коллектива, проводить планерки и совещания;

- слишком много ошибок у начальника, нет контроля, отсутствует дистанция;

- она «хороший человек», не любит обсуждений и требований, только по ее желанию можно что-то изменить;

- все хорошо;

- необходим контакт, начальник не должен уходить от ответов и решения производственных проблем.

Техническая оснащенность рабочих мест устраивает практически всех, только 1 сотрудник посетовал, что не хватает места для хранения личных дел, необходимо организовать архив.

Размер должностного оклада устраивает (в общем) только 2 работников, но последующие ответы (30000 чистыми, устраивает, в других УЗ хуже; около 30000 чистыми) убеждают в том, что сотрудники СУП даже не различают оклад и зарплату. Если же предположить, что сумму оклада они видят именно такой, то какой должна быть зарплата? Сведения о начисленной зарплате свидетельствуют о том, что отклонения от «30000 чистыми» есть только у двоих из опрошенных (табл. 3).

В систему материального поощрения, по мнению сотрудников, необходимо включать премии за интенсивность и качество; индексацию; обязательную оплату любой дополнительной работы; поощрения за освоение новой работы, например, 1С Кадры; ввести 13 и 14 зарплаты, полную компенсацию стоимости билетов; проводить «День здоровья», тренинги, конкурсы, например, «Лучший шеф-повар». Один сотрудник категоричен и уверен, что «ее нет!». Очень интересно, что предложили конкурс «Лучший шеф-повар», а не конкурс профессионального мастерства «Лучший кадровик».

В систему нематериального поощрения следует ввести поздравление руководства УЗ с Днем кадровика (вспомнили о профессиональной принадлежности!), корпоративные мероприятия, в том числе по сплочению трудового коллектива (хотя все, кроме начальника, более чем довольны межличностными и профессиональными взаимоотношениями в СУП); а вруче-

Таблица 3. Соотношение оклада и начисленной зарплаты сотрудников СУП УЗ, руб.

\begin{tabular}{|c|l|c|c|c|}
\hline \multicolumn{1}{|c|}{ № } & \multicolumn{1}{|c|}{ ФИО, должность } & Оклад & $\begin{array}{c}\text { Зарплата } \\
\text { начисленная } \\
10.01 .2015\end{array}$ & $\begin{array}{c}\text { Зарплата } \\
\text { начисленная } \\
10.04 .2015\end{array}$ \\
\hline 1 & А, специалист по управлению персоналом 1 категории & 11989 & 33234,03 & 34590,20 \\
\hline 2 & Б, начальник отдела по управлению персоналом & 15660 & 40015,00 & 41175,17 \\
\hline 3 & В, специалист по управлению персоналом 1 категории & 5572 & 31908,58 & 47357,10 \\
\hline 4 & Г, специалист по управлению персоналом 1 категории & 11989 & 41607,88 & 36086,89 \\
\hline 5 & Д, специалист по управлению персоналом 1 категории & 11989 & 57301,56 & 28653,71 \\
\hline 6 & Е, ведущий специалист по управлению персоналом & 12761 & 37779,42 & 49508,62 \\
\hline 7 & Ж, специалист по управлению персоналом 1 категории & 11567 & 7300,04 & 7300,04 \\
\hline 8 & 3, специалист по управлению персоналом 1 категории & 11989 & 28440,06 & 28653,71 \\
\hline
\end{tabular}


ние грамот и благодарностей должно осуществляться немедленно [2, с.29-34].

На вопрос «Каким образом в идеале Вы видите свою работу?» были получены ответы:

- увольняться не собираюсь;

- хотелось бы рассматривать только серьезные вопросы по функционалу СУП;

- хотелось бы остаться;

- все устраивает, а муж говорит «Я знаю, ты не уволишься!»;

- больше денег.

Получается, что работа в принципе и место работы устраивают практически всех работников, поскольку полученные ответы демонстрируют стремление к лучшему, что опять-таки подтверждает стремление к общему будущему в рамках УЗ.

Проведение интервью позволило решить следующие задачи:

- исследована специфика социально-трудовых отношений в СУП УЗ;

- определены и скорректированы особенно- сти разделения и организации труда в СУП УЗ;

- определены приоритетные организационные подходы к формированию функций и структуры СУП УЗ;

- сформулированы основные рекомендации по совершенствованию структуры СУП УЗ в целях оптимизации численности службы и повышения эффективности управления сотрудниками в целом;

- предложены оптимальная структура СУП УЗ и численность работников.

Учитывая, что СУП любой организации является именно тем структурным подразделением, которое несет ответственность, наряду с выполнением чисто «технических» задач, за формирование кадровой стратегии и политики, соответствующих целям развития, обеспечение конкурентоспособности организации за счет найма компетентных специалистов, обеспечения высокой работоспособности и благоприятного морально-психологического климата, ей следует уделить особое внимание.

\section{Библиографический список:}

1. Блинов С.В., Ревина С.Н., Кузьмина Н.М. Экономико-правовые аспекты совершенствования системы мотивации работников негосударственных учреждений здравоохранения (на примере НУЗ ОАО «РЖД») // Вопросы экономики и права, 2016. № 4.

2. Блинов С.В., Ревина С.Н., Кузьмина Н.М. Развитие системы мотивации сотрудников на основе применения ключевых показателей эффективности деятельности (на примере НУЗ «ДКБ на ст. Самара ОАО «РЖД») // Экономические науки, 2016. № 6.

3. Блинов С.В., Ревина С.Н., Кузьмина Н.М. Актуальные проблемы формирования системы целевых показателей эффективности деятельности учреждений здравоохранения // Вопросы экономики и права, 2017 . № 3. 